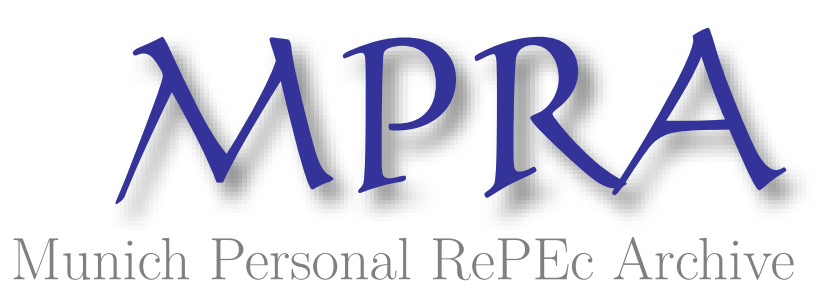

\title{
Organization of International Educational Activities at the Universities of the Third Age
}

Selecký, Erik

2017

Online at https://mpra.ub.uni-muenchen.de/84651/

MPRA Paper No. 84651, posted 05 Mar 2018 14:42 UTC 
Suggested Citation: Selecký, E. (2017). Organization of International Educational Activities at the Universities of the Third Age. In Ł. Tomczyk \& A. Klimczuk (Eds.), Selected Contemporary Challenges of Ageing Policy (103-120). Kraków: Uniwersytet Pedagogiczny w Krakowie. Doi: 10.24917/9788380840911.6

\title{
ERIK SELECKÝ ${ }^{1}$
}

\section{Organization of International Educational Activities at the Universities of the Third Age}

\begin{abstract}
The organization of an international education activity has its specifics compared to a national one. It is very important to know the differences in the very organization as well as the opinions of the individual participants. We can find differences not only in the management of education but also in the leisure activities, the nourishment, and the accommodation. Based on experiences with the organization of international events and taking part in international projects in the field of educating older adults, we put together a questionnaire to investigate some important questions related to the organization of an international event. We distributed this questionnaire at two international educational activities. We compiled the questions and answer clearly, which is going to be an asset particularly for the professional community.
\end{abstract}

Key words: International Cooperation, Lifelong Learning, University of the Third Age

\section{Introduction}

The Universities of the Third Age (UTA) in Slovakia actively cooperate with the international association of the Universities of

\footnotetext{
${ }^{1}$ Erik Selecký, Technical University in Zvolen, Centre for Further Education, Slovakia, erik.selecky@tuzvo.sk.
} 
the Third Age (AIUTA; French: Association internationale des Universités du troisième âge). There are more than 23 member countries, however, according to R.F. Swindell (2012), UTA exist in more than 60 countries around the world. AIUTA organizes an international congress once every two years and supports projects of development and cooperation of education in the third age. Another very significant organization which deals with educating the seniors is WorldU3A, established in the year 1997, which predominantly focuses on the support of e-education (Swindell, 2012). In Europe, we can talk about two basic models of educating seniors: the French and the English. The French model focuses on educating older adults at universities, and the English model focuses on making use of the public and the private spaces (Selecký, 2014). According to J. Yenerall (2003), Finish UTA students attend lectures at universities in combination with local educational groups by means of the open-door policy. For further comparison, we can characterize education in Malta, where there is a combination of university education supplemented by group session (Formosa, 2012). Additional examples in the world tell us about the typical French model which is implemented in Canada (Lemieux, 1995), and for example in Taiwan, where educating the seniors is not connected to universities but is managed and financed by the local authorities and the teaching is done by professional teachers (Huang, 2005). Based on these examples we can see several different approaches to educating the seniors.

The education at UTA cannot be defined as an education in senior age, but in consideration of the age structure and the possibility of acceptance in Slovakia, we have to talk about old adults and seniors. The managers of individual UTA have to communicate with the students whose age structure has a wide range from 45 years old to minimally 80 years of age or older.

A high added value for UTA students apart from the educational process, excursions, cultural and social, is the organization of international educational activities. We know that the highest interest is in the language and the computer education. Many of the students have families abroad and need to keep in touch with them, and in most cases, talk to the grandchildren. Another important factor is a high mobility which contributes to 
the more frequent use of the language competencies of the individual.

If we want to increase the motivation of UTA students for language education, we have to think about a way to implement it. Of course, UTA should not replace travel agencies, but they do have certain options to develop international cooperation through various project activities. UTA at the Technical University in Zvolen has a long tradition of more than 20 years. It belongs to the first UTA in Slovakia. We have more than 450 students in 18 academic fields. In 2011, we successfully managed to take part in an international project financed from the grant scheme Grundtvig Programme. Two years later, we were in another similar project, and nowadays we are in projects financed from the scheme Tempus and Erasmus Plus. We are going to introduce the basic differences between these programs briefly.

The Grundtvig Programme was a part of a European Lifelong Learning Programme (LLP 2007-2013). It focused on the European cooperation in the field of adult education. Center for Continuing Education (CCE) at the Technical University (TU) in Zvolen focused predominantly on the subprogram: "Learning partnerships," which supported projects of two-year cooperation in which educational institutions for adults from at least three countries took part. The emphasis was put particularly on an exchange of information and experiences and on an active project participation of adult learners in projects (Grundtvig, 2016).

The Tempus program is a part of an EU program which supports the modernization of the university education in the near surroundings of EU. It is focused on countries in Eastern Europe, Central Asia, Western Balkans, and the Mediterranean region. Especially consortia of institutions composed particularly of universities are being supported (Tempus, 2016).

The Erasmus Plus program provides grants for a wide spectrum of events and activities in the field of education, vocational training, youth, and sport. The program gives an opportunity to students, pupils of vocational training, pedagogical employees, youth workers and volunteers to spend time abroad and improves their knowledge, skills, and employability. The program supports organizations which can join the project 
cooperation and within the partnerships share innovations about education, vocational training, and youth (Erasmus Plus, 2016).

The main objective of the contribution is a familiarization with the results of the research which we carried out on 138 participants of international educational activities. The participants were managers, lecturers, and UTA students. We asked for their opinion: How to organize international educational activities? The secondary objective was an enrichment of theoretical knowledge and experience during the implementation of international educational activities for older adults and seniors.

\section{The Methodology of the Research}

The objective of the research is the investigation of the opinions of the participants of international educational activities who are commenting on the organization itself. Another objective of the research is the investigation of individual needs of an international educational event participant.

The main tool for finding the information was an anonymous questionnaire. The questionnaire was made especially for the purpose of improving the work organization-mainly of the international educational activities which are organized by CCE at TU in Zvolen. Since the employees of CCE attend multiple international events at home and abroad yearly, we felt a strong need to find out what the opinion of the participants is in the organization itself. In order for this questionnaire not to be generally thought of only for further education-it is closely linked mainly with the organization of international events in the environment of UTA. We put the questionnaire together in the year 2015, and it was distributed for the first time at the final meeting of the project named: "My passion, happiness - add to favorites" in June 2015 (Lubsko, Poland). At this meeting, there were around 100 participants from 6 countries of the European Union (Poland, Portugal, Turkey, Lithuania, Romania, and Slovakia). We arranged an individual distribution of the questionnaire, where we had more than $70 \%$ submission rate. This questionnaire was also translated, apart from the English language, to the Polish language because of a high number of resident seniors who did not speak the English language. We chose the 
following phase in the $4^{\text {th }}$ year of an international sports olimpic games for UTA students which took place in September 2015 in Zvolen. We distributed it to participants of olimpic games from these countries: Ukraine, Czech Republic, Poland, and Slovakia. The number of questionnaires which we received back was more than 60. It is very important to note that the target group was not chosen by chance, but they were participants of an international event, who took part in several activities, and the length of the very activity was in the interval of 4-5 days. By means of the questionnaire, we addressed three basic target groups: UTA managers (14), UTA lecturers (28), and UTA students (96). By estimation, we can split this group to $10 \%-20 \%-70 \%$.

Processing and evaluation of the questionnaires-we evaluated each question individually in the Excel software. We used charts and graphs for the evaluation.

During processing the results and the discussion, we used the method of comparison and abstraction.

\section{Results and Discussion}

We divided the questionnaire structure into two parts. The first part deals with questions which relate to practical experiences with the organization of international activities and the second part investigates basic identification data about the participant.

We are going to present all questions asked to the respondents together with possible answers, and we are also going to clarify the objective of the author as to why he chose this question. In the following part, we are going to graphically represent some of the answers which were a result of the research, and we are going to enrich them with an own commentary.

1. question: What kind of transportation do you prefer? (Car, Bus, Train, or Plane)

From an economic standpoint, we mainly prefer an automobile transportation during the mobility of the participants at a shorter distance. Apart from the management, our students also participate in driving the car. It is more economical when we do not have to order a bus, in which case not only the kilometers but also the bus waiting fee has to be paid for. If you travel for more days, the price for the bus waiting fee reaches high amounts. The 
train is considered to be the most comfortable way of traveling within Europe. However, the main disadvantages are a high price as well as a problematic connection to smaller places. Colleagues from Portugal and Turkey generally marked the plane, which is self-evident because their distance is incomparably larger than distances in Central Europe. more)

2. question: How many days do you prefer? $(1,2,3,4,5$, or

It is a significant indicator of the management of an international event. It is necessary to realize, that a sensitive approach to the organization is inevitable, mainly due to distinct nationalities, customs, cultures, and religions. It is also necessary to divide the activity into educational, cultural, social. If I do an international education training, I have to supplement it with a suitable social side. It is also necessary to remember that the participants like various cultural sights and want to find out as much as possible about the country.

3. question. What type of accommodation do you prefer? (Single-bed, Two-bed, Three-bed, Four-bed)

A very practical question. We are finding out ourselves that there are distinct approaches. If the management finances the activity, the participants are mostly likely to sleep alone, and when they have to finance it by themselves, it is not a problem to share a room with more people. The economy plays a significant role while occupying the rooms.

4. question: What time do you prefer for lunch? $(11-12,12-$ $13,13-14,14-15)$

5. question: What time do you prefer for dinner? $(17-18,18-$ 19, 19-20, 20-21)

From a multicultural and mainly a geographical viewpoint, the questions of planning lunches and dinners are very important. We know that countries in the south of Europe prefer later lunches and dinners. Sometimes us, Central Europeans, shake our heads at how it is possible to dine during later hours and then go to sleep. It is necessary to set the time distribution properly to avoid complaints from the side of the participants.

6. question: How many hours of free time a day do you prefer? (0, 0-1, 1-2, 2-3, 3-4, 4-more) 
We know from practice that a person needs time to oneself. The question is how much. Some participants are satisfied with a filled program from morning till evening; others need more unmanaged time. During planning, it is necessary to foresee a time reserve as well as the number of the participants. When we organize a "getting to know you" activity, the coefficient of the time reserve has to be higher.

7. question: What type of activity do you prefer at a meeting? (max. 3) (Sport, IT, Communication in English, Music, Dance, Drawing, Singing, Handiwork)

The choice of activities which we offered to the participants is based on years of observation of activities at international meetings. We found out that sport-dance-singing are the basic icebreaking tools among participants.

8. question: What type of sport do you prefer at a meeting (max. 3) (Football, Basketball, Volleyball, Pétanque, Bowling, Archery, Zumba, Table-tennis, Yoga, others...)

Sport and physical activities are a very important component of every multi-day event. As defined by the author M. Šerák (2009) "Even now, physical education and sport represent an important component of free-time education not only for adults but also for seniors." This is confirmed by another author focused on educating the seniors D. Gracová (2015) "Physical activities do not only prolong age but above all, add to the contentment, the self-sufficiency, the independence, develop the physical ability and have a great influence on the whole human body." By asking this question, we were searching for an answer to mainly discover what type of sports suits a particular age group.

9. question: What type of free-time activities do you prefer? (Shopping, Visit of a historical center-museums, castles, Sport, Nature)

Often we have come across participants preferring to go to the shop to buy something nice for their relatives, where they spent a lot more time than at the city tour itself. We are searching for an answer, whether the participants truly prefer shopping centers over interesting cultural, sport or nature activities.

10. question: What type of cuisine do you prefer? (Own national, international, or combination of both) 
At first glance, it is not an important question. However you would not believe, how much can an ignorance of this answer complicate and significantly disrupt the event organization. It is especially necessary to think about other cultures and take into account what specifics they have on their menu. It is ideal when lunches and dinners are buffet-style. However, this is not always feasible. Some nations prefer more vegetables; some do not eat beef, some prefer fish. Some are vegetarians, vegans. It is necessary to prepare properly for differences in nutrition and not forget to ask the participants whether they have any specific requests, rather than deal with meal replacement on the go, which does not always have to be a success.

11. question: What types of activities do you prefer for a better learning of the English language at a meeting? (Listening to a lecture, Communication in a pair, Communication in a small group, Communication in a large group)

Most older adults prefer communication in a foreign language in a large group. They do not like to draw attention to themselves; they rather want to "hide" behind someone else. It is an interesting finding mainly from a time standpoint-long-term research, how and if at all people change their opinion.

12. question: What type of educational tool do you use for learning the English language? (School, Computer, Movies, Books, Verbal communication, None, Other...)

Whether we like it or not, the English language is getting preferable as the world communication language. We know that some countries - mainly the Francophone ones, are advocates of protecting their mother language, and even though they can speak the English language, they do not want to communicate. We directed our question at the English language because we suppose that the English language is the number one at international meetings. It is necessary to confirm a well-known matter of fact "The more languages you know, the more you are human." This matter of fact is confirmed at our meetings, and sometimes the fundamentals of a language are enough to remove the basic communication barriers. 
13. question: What kind of communication do you prefer before and after a meeting (activity)? (Post, E-mail, Skype, Social networks-Facebook..., Other)

It is interesting to observe how fast the development of communication channels between organizations and people are moving forward. If we communicated via e-mail and the post several years ago, today it is moving to Skype, Facebook, and other social networks. This is connected to the question which should give an answer about the most effective communication tool for a particular age group. However, we have to emphasize that the limit of information and communications technology (ICT) knowledge is constantly shifting and the ICT knowledge and skills are constantly widening.

\section{Identification Data}

Nationality, Sex, Age, Economic position (Employed, Unemployed, Retiree), Level of education (Primary education, Secondary education, Higher education), Living with (number of residents)

\section{Answers to Identification Data Questions}

As we mentioned, the distribution of the questionnaire was carried out at an international educational activity in The Republic of Poland and in Slovakia. Due to this reason, there is a high portion of Slovak and Polish nationality. A great benefit is the representation of 8 nationalities. From a geographical viewpoint, it is mainly Central Europe. However, the representation of Turkish and Portuguese nationality has a significant influence.

The highest age representation is among respondents from 61-70 years. However, it is necessary to add that representation of the retiree age to the working one is 2:1 (i.e., $66 \%-33 \%$ ). Since the majority are UTA students, it is also confirmed by the sex statistics, that there are more than $70 \%$ women. The average in Slovakia is more than $80 \%$. This fact also confirms that more than two-thirds of UTA students are female. An interesting result is an answer to the level of education - up to $67 \%$ state to have a higher education. This data shows that the majority of respondents apart from UTA students have a university degree because they are 
managers and UTA collaborators and the majority of the student participants of international mobility has a higher education.

Figure 1 The Nationality of Respondents

\section{The nationality of respondents}

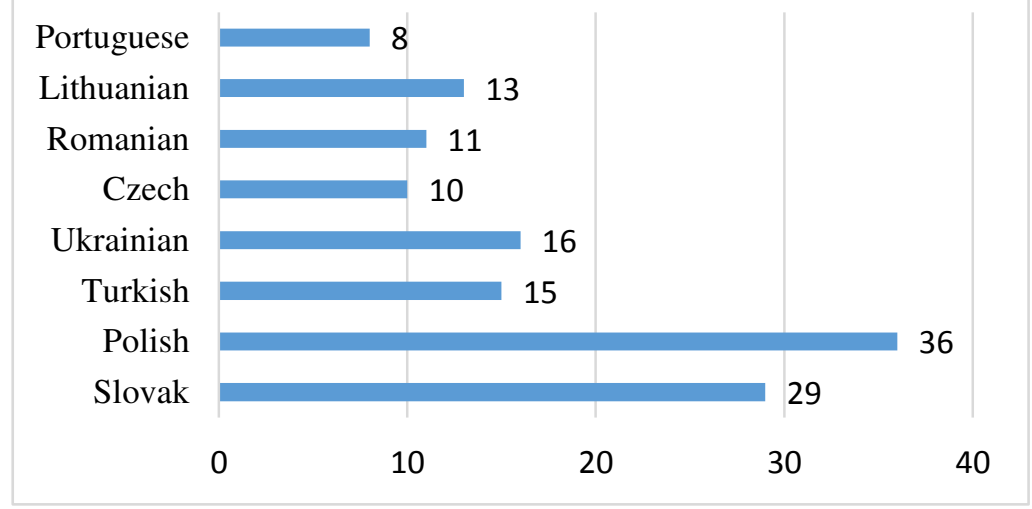

Source: Own elaboration.

Figure 2 The Age

\section{The age}

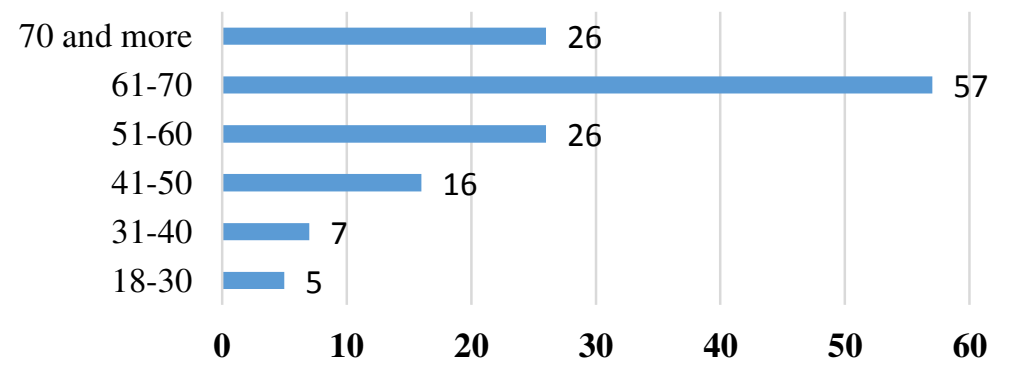

Source: Own elaboration. 
Table 1 Sex, Economic Position, and Level of Education

\begin{tabular}{|l|c|c|c|}
\hline Sex & Woman & \multicolumn{2}{|c|}{ Man } \\
& $92(71 \%)$ & $29 \%)$ \\
\hline $\begin{array}{l}\text { Economic } \\
\text { position }\end{array}$ & Employed & Unemployed & Retiree \\
& $47(33 \%)$ & $1 \%)$ & $93(66 \%)$ \\
\hline Level of & Primary & Secondary & Higher \\
education & education & education & education \\
& $0(0 \%)$ & $45(33 \%)$ & $92(67 \%)$ \\
\hline
\end{tabular}

Source: Own elaboration.

Other Answers to Questions 1-13

The answer to question n.1: The preferred vehicle is the airplane, the bus, and the car (30\%). The train was placed on the fourth place with only $11 \%$. This confirms our assumption that despite the train popularity as a transportation, an important role is played by a combination of time and price.

The answer to question n.2: We can consider three days to be ideal, but the data about five days also stands out. These results can be influenced by a viewpoint factor. From the organizer's standpoint, the optimum of working days is 2-3, from the participant's standpoint, it is more than two days, mainly because when I travel I want to experience as much as I can and basically, it is not worth going anywhere for 2-3 days when I have to count in the journey there and back, which usually takes approximately 2 days.

The answer to question n.3: A very unexpected result in terms of percentages. Up to $82 \%$ of all respondents' state they would be willing to be accommodated in a two-bed room. We can assume two reasons for this. On the one hand, they are aware of the high costs of accommodation in a single-bed room, and on the other hand, we suppose the participants would rather stay in a pair than alone.

The answer to question n.4: A clear answer to the question asked is a lunch organization between 12 and 14 PM, in addition to that a half of all respondents leaning towards the 13-14 PM alternative. From an organizational standpoint, it is a very valuable information. It is not necessary to "push" the lunch to around 12 
PM, as we are used to in Central Europe, and so we do not have to be afraid to postpone it till $13 \mathrm{PM}$. If we reviewed the questionnaire answers in detail, the participants from Portugal and Turkey are in the majority leaning towards lunch organization in the 13-14 PM interval.

The answer to question n.5: By comparing all the options, it is clear that the best dinner organization is between 18-19 PM. If we had to "move" the dinner time, it should rather be later than earlier.

The answer to question n.6: A profoundly important question and appertaining answers. It follows from the questionnaire that respondents need 2 to 3 hours of time daily, which they want to use according to their taste. Whether for rest or other activities which they need to perform. We often meet with managers and UTA lecturers having to deal with work issues, and in the case of a "loaded" program, they have to find a space for it. If they do not find it during the day, they often struggle and are not focused on activities during the international event.

\section{Figure 3 Question n.8: What Type of Activity Do You Prefer at a Meeting (Max. 3)}

What type of activity do you prefer at a meeting (max.3)

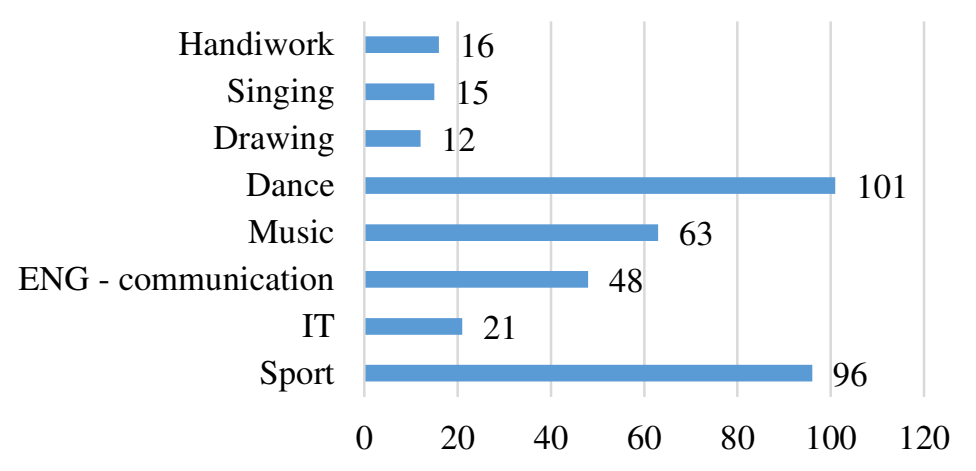

Source: Own elaboration. 
The answer to question n.9: Almost half of the respondents stated that they prefer sight-seeing during the free time. It is very gratifying that the smallest percentage out of all answers came to the international activity to shop. During the organization, the natural beauty of the particular region should not be forgotten because it feels good to take a walk-in nature after activities such as the educational ones.

Figure 4 Question n.9: What Type of Sport Do You Prefer at a Meeting (Max. 3)

What type of sport do you prefer at a meeting (max.3)

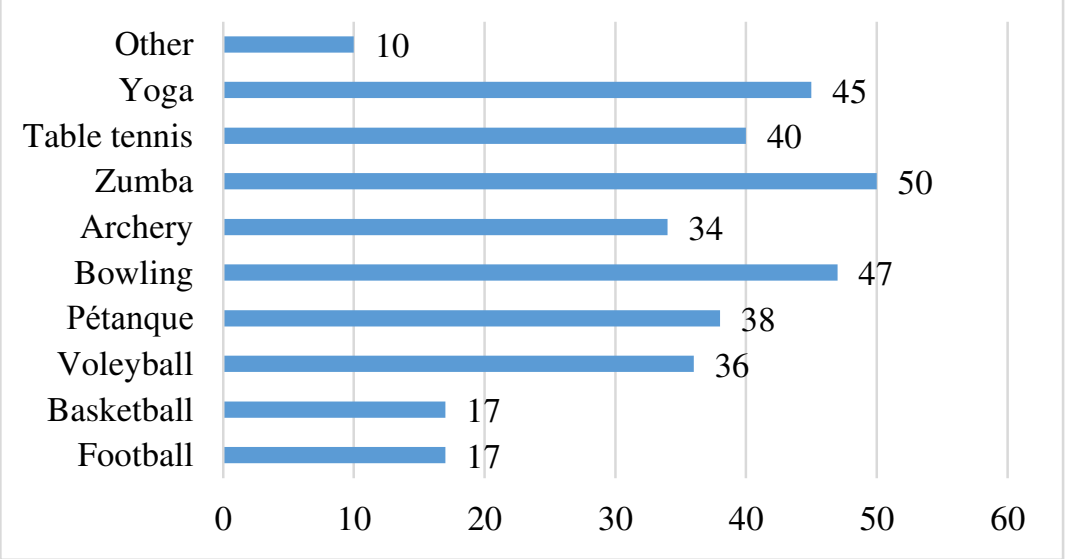

Source: Own elaboration.

The answer to question n.10: Not everybody enjoys national cuisines of particular states, and a large number of people do not want to try something new. Despite these assumptions, there is a very positive result of $85 \%$, in which the combination of food appears as the wisest solution. We recommend arranging national cuisine on some days and international-accepted by the general public, on others.

The answer to question n.11: Up to $54 \%$ of respondents stated that they prefer learning the English language by 
communication in a small group. It is gratifying that listening to lectures, communication in a pair and a large group placed evenly at the second place. It means that they are not interested in hiding in a large group, and communication in a small group is not a problem.

The answer to question n.12: The answer school and verbal communication ended up leading significantly. Since the respondents are mostly UTA students, it is also confirmed by this answer, that they are learning the English language at school and generally prefer verbal communication over the written one. The computer has quite a high percentage, and we assume its use to be a significant educational component.

The answer to question n.13: Almost 50\% of the respondents stated that they prefer e-mail communication. The percentage of social networks is very interesting, and it ranges from $23 \%$. Due to an increasing use of social networks not only for communication purposes, we assume a constant development of this type of communication channel. It follows that it is important to pay increased attention to the creation and actualization of social networks for the organization of educational events.

\section{Table 2 Answers to Questions 1-6 and Questions 9-13}

\begin{tabular}{|c|c|c|c|c|c|c|}
\hline 1. & $\begin{array}{c}\text { Car } \\
42(27 \%)\end{array}$ & $\begin{array}{c}\text { Bus } \\
48(31 \%)\end{array}$ & $\begin{array}{c}\text { Train } \\
18(11 \%)\end{array}$ & $\begin{array}{c}\text { Airplane } \\
49 \\
(31 \%)\end{array}$ & & \\
\hline 2. & $\begin{array}{c}\text { One } \\
2(1 \%)\end{array}$ & $\begin{array}{c}\text { Two } \\
23(17 \%)\end{array}$ & $\begin{array}{c}\text { Three } \\
38(28 \%)\end{array}$ & $\begin{array}{c}\text { Four } \\
27 \\
(20 \%)\end{array}$ & $\begin{array}{l}\text { Five } \\
34 \\
(25)\end{array}$ & $\begin{array}{c}\text { And } \\
\text { more } \\
13 \\
(9 \%)\end{array}$ \\
\hline 3. & $\begin{array}{c}\text { 1-bed } \\
18(13 \%)\end{array}$ & $\begin{array}{c}\text { 2-bed } \\
112(82 \%)\end{array}$ & $\begin{array}{l}\text { 3-bed } \\
7(5 \%)\end{array}$ & $\begin{array}{l}\text { 4-bed } \\
0(0 \%)\end{array}$ & & \\
\hline 4. & $\begin{array}{l}11-12 \\
\text { hours } \\
7(5 \%) \\
\end{array}$ & $\begin{array}{c}\text { 12-13 hours } \\
56(41 \%)\end{array}$ & $\begin{array}{c}13-14 \text { hours } \\
65(49 \%)\end{array}$ & $\begin{array}{l}14-15 \\
\text { hours } \\
7(5 \%) \\
\end{array}$ & & \\
\hline 5. & $\begin{array}{c}17-18 \\
\text { hours } \\
15(11 \%)\end{array}$ & $\begin{array}{c}18-19 \text { hours } \\
70(52 \%)\end{array}$ & $\begin{array}{c}19-20 \text { hours } \\
40(29 \%)\end{array}$ & $\begin{array}{c}20-21 \\
\text { hours } \\
11(8 \%)\end{array}$ & & \\
\hline
\end{tabular}




\begin{tabular}{|c|c|c|c|c|c|c|}
\hline 6. & $\begin{array}{l}0 \text { hours } \\
4(3 \%)\end{array}$ & $\begin{array}{c}0-1 \text { hours } \\
8(6 \%)\end{array}$ & $\begin{array}{l}1-2 \text { hours } \\
45(33 \%)\end{array}$ & $\begin{array}{c}2-3 \\
\text { hours } \\
63 \\
(46 \%)\end{array}$ & $\begin{array}{c}3-4 \\
\text { hours } \\
16 \\
(11 \%)\end{array}$ & $\begin{array}{c}4 \\
\text { hours } \\
\text { and } \\
\text { more } \\
1 \\
(1 \%) \\
\end{array}$ \\
\hline 9. & $\begin{array}{l}\text { Shopping } \\
29(16 \%)\end{array}$ & $\begin{array}{l}\text { History } \\
84(48 \%)\end{array}$ & $\begin{array}{c}\text { Sport } \\
30(17 \%)\end{array}$ & $\begin{array}{c}\text { Nature } \\
34 \\
(19 \%)\end{array}$ & & \\
\hline 10. & $\begin{array}{c}\text { National } \\
12(8 \%)\end{array}$ & $\begin{array}{c}\text { International } \\
10(7 \%)\end{array}$ & $\begin{array}{c}\text { Combination } \\
115(85 \%)\end{array}$ & & & \\
\hline 11. & $\begin{array}{c}\text { Lecture } \\
21(14 \%)\end{array}$ & $\begin{array}{c}\text { Pair } \\
25(16 \%)\end{array}$ & $\begin{array}{c}\text { Small group } \\
81(54 \%)\end{array}$ & $\begin{array}{c}\text { Large } \\
\text { group } \\
22 \\
(15 \%)\end{array}$ & $\begin{array}{l}\text { Other } \\
2 \\
(1 \%)\end{array}$ & \\
\hline 12. & $\begin{array}{c}\text { School } \\
57(31 \%)\end{array}$ & $\begin{array}{l}\text { Computer } \\
26(14 \%)\end{array}$ & $\begin{array}{l}\text { Movies } \\
14(8 \%)\end{array}$ & $\begin{array}{c}\text { Books } \\
15(8 \%)\end{array}$ & $\begin{array}{c}\text { Orally } \\
56 \\
(31 \%) \\
\end{array}$ & $\begin{array}{c}\text { None } \\
14 \\
(8 \%) \\
\end{array}$ \\
\hline 13. & $\begin{array}{c}\text { Post } \\
16(9 \%)\end{array}$ & $\begin{array}{c}\text { E-mail } \\
90(48 \%)\end{array}$ & $\begin{array}{c}\text { Skype } \\
34(18 \%)\end{array}$ & $\begin{array}{c}\text { Soc. } \\
\text { Netw. } \\
44 \\
(23 \%)\end{array}$ & $\begin{array}{c}\text { Other } \\
4 \\
(2 \%)\end{array}$ & \\
\hline
\end{tabular}

Source: Own elaboration.

Among the most popular activities, we can definitely place dance and sport. We can confirm that apart from dance people enjoy singing (which was not really confirmed in the research) and doing sports. They favor activities which connect people and in which they do not need to use language skills for communication that much.

It is not clear which type of sport is the favorite, a preferable one but we can state that the sports trio zumba, yoga and bowling has a slight lead. As the author, D. Gracová (2011) states "the gained knowledge has significance for health, for physical as well as the psycho-social and cultural development of a human." The first two sports (activities), I would attribute to the high percentage of women as respondents, and we can understand bowling as a sport, in which physical abilities are reduced, and we can perceive it as an activity during which we have fun, debate, 
and have a drink. Chess, as well as dance, appeared among other sports.

\section{Conclusion}

By organizing international education activities, we not only widen our personal knowledge but mainly the knowledge of people for whom we organize these events. We do not live on a deserted island but on a continent called Europe, where a multitude of nations and nationalities live. It is important to use the opportunity to become familiar with the culture, the traditions, and the customs of other nations. We have a significant number of opportunities to take part in international projects which help reduce the cultural, the social and the economic differences in Europe. Not only through a various project of the European Union, but mainly from a personal initiative, let us enable the wide surroundings to take part in these wonderful multicultural and international education activities.

In today's age of advanced ICT technology, we must not forget about electronic education for seniors at UTA. We have to enable e-learning, online, offline courses mainly to our students who live in remote areas outside the big cities (Swindell, 2000). We can talk about the large development of Online Universities of the Third Age in the United Kingdom, Australia, and New Zealand. Virtual universities which use electronic support, emails, and Skype are being established (Swindell, 2002; Tomczyk, 2015). All of these activities and actions should support the development of senior education in the world.

We agree with several authors that new technologies should not replace on-site learning. Social contacts among seniors are very important. On the other hand, we need to keep abreast of the times. The present time, as well as the near future, require the inclusion of new technologies in education and the preparation of conditions not only for students but also for lecturers and organizers. ICT technologies are constantly developing; therefore, we should have personal capacities to deal with this issue. They should affect not only organizers, lecturers but also students. In this environment, a target group of seniors is coming to us from which we expect a strong demand for new technologies. Seniors 
are not only going to expect learning about new technologies in the form of ICT courses but the fact that lecturers themselves are going to use this type of tool for significant improvement and a quality increase in the pedagogical performance in the form of PowerPoint, e-books, pdf formats, DVD demonstrations and others.

The near future is going to show that seniors are also increasing their knowledge potential and they are going to make greater demands on the educational process itself.

\section{References}

Erasmus Plus, Program Information. (2016). Retrieved from www.erasmusplus.sk/index.php?sw $=70$

Formosa, M. (2000). Older Adult Education in a Maltese University of the Third Age: A Critical Perspective. Education and Ageing, 15(3), 315-338.

Formosa, M. (2012). Education and Older Adults at the University of the Third Age. Educational Gerontology, 38(2), 114-126.

Gracová, D. (2011). Moderné formy realizácie pohybových aktivít seniorov v kontexte záujmového vzdelávania [Modern forms of realization in movement activities for seniors in the context of interest education]. In Záujmové vzdelávanie (pp. 100-104). Bratislava, Banská Bystrica.

Gracová, D. (2015). Vplyv pohybu a význam pohybových aktivít na vitalitu seniorov [Impact of movement and the importance of physical activities for seniors' vitality]. In Ł. Tomczyk \& Š Chudý (Eds.), Aktywna starość w perspektywie społecznokulturowo-edukacyjnej. Společenské, kulturni a vzdělávací aspekty fenoménu aktivního stárnutí [Active old age in the sociocultural-educational perspective] (pp. 51-78). Olomouc, Kraków: Uniwersytet Pedagogiczny.

Grundtvig, Program Information. (2016). Retrieved from http://web.saaic.sk/llp/sk/_main.cfm?obsah=m_uvodna_stranka. htm\&sw_prog=5

Huang, C.-S. (2005). The Development of a University for Older Adults in Taiwan: An Interpretive Perspective. Educational Gerontology, 31(7), 503-519.

Lemieux, A. (1995). The University of the Third Age: Role of Senior Citizens. Educational Gerontology, 21(4), 337-344. 
Selecký, E., et al. (2014). Univerzity tretieho veku na Slovensku [University of the Third Age in Slovakia]. Zvolen: Technická univerzita vo Zvolene.

Šerák, M. (2009). Zájmové vzdělávání dospělých [Interest in adult education]. Praha: Portál.

Swindell, R. (2000). A U3A Without Walls: Using the Internet To Reach out to Isolated Older People. Education and Ageing, 15(2), 251-263.

Swindell, R. (2002). U3A Online: A Virtual University of the Third Age for Isolated Older People. International Journal of Lifelong Education, 21(5), 414-429.

Swindell, R. F. (2012). Successful Ageing and International Approaches to Later-life Learning. In G. Boulton-Lewis \& M.

Tam (Eds.), Active Ageing, Active Learning. Issues and Challenges (pp. 35-65). Dordrecht, New York: Springer.

Tempus, Program Information. (2016). Retrieved from http://eacea.ec.europa.eu/tempus/programme/about_tempus_en.p hp

Tomczyk, Ł. (2015). Vzdělávání seniorů v oblasti nových médii [Education of eledery in area of new media]. Praha: Asociace Institucí Vzdělávání Dospělých ČR, Praha. 